\title{
住宅室内のカビ污染と防止に関する研究 \\ （その 2 ）換気による室内カビ污染防止に関する実証調查
STUDY ON THE CONTAMINATION CONTROL OF FUNGI IN DWELLINGS

Part 2 Verification of ventilation effectiveness against prevention of fungal outbreaks in dwellings

\author{
小峯 裕已*, 荒井卓也**, 長谷川 永** \\ Hiromi KOMINE, Takuya ARAI and Hisashi HASEGAWA
}

\begin{abstract}
It is well known that fungi may scarcely germinate or grow in the house with sufficient ventilation. This effect may be a rule of thumb because scientific background such as experimental data or field test data are not shown.

This study aims to clarify the ventilation effectiveness against prevention of fungal outbreaks in dwellings on the basis of full scale tests. A method of pair comparisons between a room with proper ventilation and a room without ventilation were adopted. In these rooms, building materials such as tatami mat, which is the Japanese traditional flooring, made of straw mat. plywood, wallpaper and so on were placed in order to observe germination or colony forming.

Germination or colony forming on the building materials, set in the room with sufficient ventilation, were not confirmed although fungal contamination occurred in the room without ventilation.

Measuring data of temperature and relative humidity in both rooms were compared with the thermal conditions preventing the growth of 4 kinds of hygrophile fungi . as was reported in the former paper. Measuring data in the room without ventilation were overlapped with the specified thermal region, nevertheless thermal condition in the room with proper ventilation was beyond the specified thermal region.
\end{abstract}

Keywords: Prevention against Fungal Pollution. Ventilation, Full scale Tests, Indoor Temperature and Relative Humidity カビ污染防止，換気，実証実験，温湿度条件

\section{1.はじめに}

近年、居住者の快適な住環境に対する要求の高まりや、住宅の断 熱・気密性能等のシェルター性能の向上や椧暖房設備の充実等によ り、室内温熱環境は、大幅に改善されている。しかしながら、高気 密化に対応した換気設備の設置は、必ずしも十分とは言い難い。従 来の住宅のように、漏気を換気替わりに利用寸ることができないこ れらの住宅では、漏気減少に伴って換気が不足しがちである。また、 リゾートマンションのように不在期間の長い建物では、空を閉め 切っている時間が長いため、やはり換気が不足しがちである。

室温の最適化と換気不足があいまって、最近の多くの住宅では、 ダニやカビ等の微生物污染やこれに伴う健康影響等の発生が報告さ れており、大きな社会問題となることが㲘念される。

ところで、従来から微生物污染に対する有効な防止対策の一つと して、換気の促進が举げられているが、その勃果の有用性に関寸る 学術的な根拠は見当たらない。本研究では、換気が室内力ビ污染防 止に果た寸役割を明らかにすることを目的に、換気状況が異なる複 数の居室内に長期間曝露した建材上へのカビの発生状況を観察する とともに、室内温湿度の測定を行い、換気の有無によりカビの発生 状況に差異が認められること、換気を行った部屋の室内温湿度付前 報1)で明らかにした「カビの発生し易い温湿度範囲」から逸脱して
いることを確認し、換気のカビ発生に対する抑制効果を実証したの で、その結果を報告する。

\section{2.カビ活染防止に対する換気効果検証のための実際の居室を 用いたー対比較実験}

\section{1 実験目的}

平面が同一で隣接する居室 2 室を用い、一方は換気を行う居室、 他方は換気を行わない居室として、これら2室に設置したカビ胞子 照濁液塗布の建材へのカビ発生状況を観察することにより、カビの 生育に対寸る換気の抑制効果を実証する。

\section{2 実験概要}

\section{（1）実験対象とした菌種}

住宅内で出現頻度の高いAspergillus属注i）を用いた。

（2）使用した基材

畳表・ベニヤ・壁紙・布・餅を用いた。

(3) 使用した居室

図 1 に、本実験で使用した居室の平面図を示寸。神奈川県藤沢市 にある企業の独身寮の1階北側に位置寸る2部屋を使用した。両室 の床面積は各々 $12.04 \mathrm{~m}^{2}$ と等しく、気積は28. $88 \mathrm{~m}^{3}$ である。
* 千葉工業大学建築学科 教授.工博

** 松下精工㑣空調技術研究所
Prof., Chiba Institute of Technology, Dr. Eng.

Air Conditioning Research and Development Institute, Matsushita Seiko Co. Ltd. 


\section{（4）実験方法}

1) 換気の調整方法

カビ污染防此に対する換気の効果は、室内相対湿度の低減、及び、 室温の低下にあると考えられるので、換気を行う居室の換気恃常時 一定量の換気を行うのでなく、外気エンタルピが室内空気エンタル ピより低い時だけ換気を行うような工夫を施した。換気有りの部屋 には、給気用・排気用の換気扇（パイプファン）を設置して、熱交 換型換気ニニット用コントローラーを用いて、上述のエンタルピの 条件下でのみ、換気扇を運転するような自動制御運転とした。な拉、 2 台の換気扇の間には仕切板を設置して、給気と排気とが短絡しな いよう配慮した。また、換気無しの居室は、空を閉鎖したままの状 況として、特に手を加えていない。両室の換気状況を定量的に把握 するため、「JIS A 1406 屋内換気量測定法（炭酸ガス法）」2) に従って、換気回数を測定した。測定結果老表 1 に示寸が、換気無 しの部屋でも換気回数 1 回程度の漏気が存在したが、換気扇運転時 の両室の換気状況には有意な差異があるこ言える。

2) 室内温湿度の調製方法

両室とも相対湿度の測定值に基づいて運転を制御与る超音波加 湿機を設置し、換気有りの部屋は換気を行わない状態で相対湿度 $80 \%$ R H以上を維持するように作動させ、換気無しの部屋は常に相 対湿度 $80 \%$ R H以上を維持するように作動させた。な拉、実験期間 が長期に亘るため、暴露基材が乾燥しすぎる恐れがある。

表 1 換気回数測定結果

\begin{tabular}{|c|c|c|}
\hline & 換気有りの部屋 & 換気無しの部屋 \\
\hline 換気扇ON & 5. T回. h & - \\
\hline 換気扇OF F & 2.6 回, ' $h$ & 1.1回 ' $\mathrm{h}$ \\
\hline
\end{tabular}

このため、超音波加湿機の噴霧口を曝露基材に向汁、超音波加湿器 作動時には噴霧される霧状水滴により曝露基材が濡れた状態々なる ように配慮した。両部屋とも䦥め切って、観察や超音波加湿機八の 水補給時以外の出入りはないもの上し、室温は自然気温こした。
3）曝露基材の調整方法

前報1）と同様の調製過程を経て、カビ胞子緊濁液を深布した曝露 基材を準備した。

4 ）曝露期間・観察期間

写真 1 に示すように調製した曝露基材を各々の部屋中央の台上へ 設置し、1990年12月4日〜18日までの14日間暴露した。曝露期間中 1 日 1 [四、基材上八のカビ発生の有無、発生後の生育面積を目視に より観察した。各部屋の室内温湿度の経時変化は、神栄株式会社製 温湿度センサー（RHUー650-232）で自動測定した。

5 ) 評価尺度

カビの発育度に関する評価尺度は、「JIS Z 2911 カビ抵抗性試 験方法」3）に準じた基材八の発育面積の大小に基づく4 段階尺度を 用いた。

\section{3 実験結果、及び、考察}

表 2 に換気有りの部屋と無しの部屋でのカビ発生状況の観察結果 を示寸。

表 2 換気の有無によるカビ発生状況の差異

\begin{tabular}{|c|c|c|c|c|c|}
\hline & 壁紙 & ベニヤ & 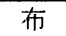 & 餅 & 畳 \\
\hline 換気有り & ND & ND & ND & ND & ND \\
\hline $\begin{array}{c}\text { 換気無し } \\
\text { (カビ発生日) }\end{array}$ & $\begin{array}{c}0 \\
(12 / 13) \\
10 \text { 日且 }\end{array}$ & ND & ND & $\begin{array}{c}\overline{\mathrm{C}}) \\
\left(122^{\prime} 8\right) \\
5 \text { 日目 }\end{array}$ & ND \\
\hline
\end{tabular}

菌采の生育が認められない

菌系の生育面積が全面䄼の1/3末満・・。

菌系の生育面積が全面積の $1 / 3$ 以上・・・ (

換気有りの部屋では、全ての基材ともカビ発生が全く認められな かったのに対して、換気無しの部屋では壁紙や餅の上にカビが発生 した。

図 2 に、実験期間中のある 2 日間に招ける室内外温湿度の経時変

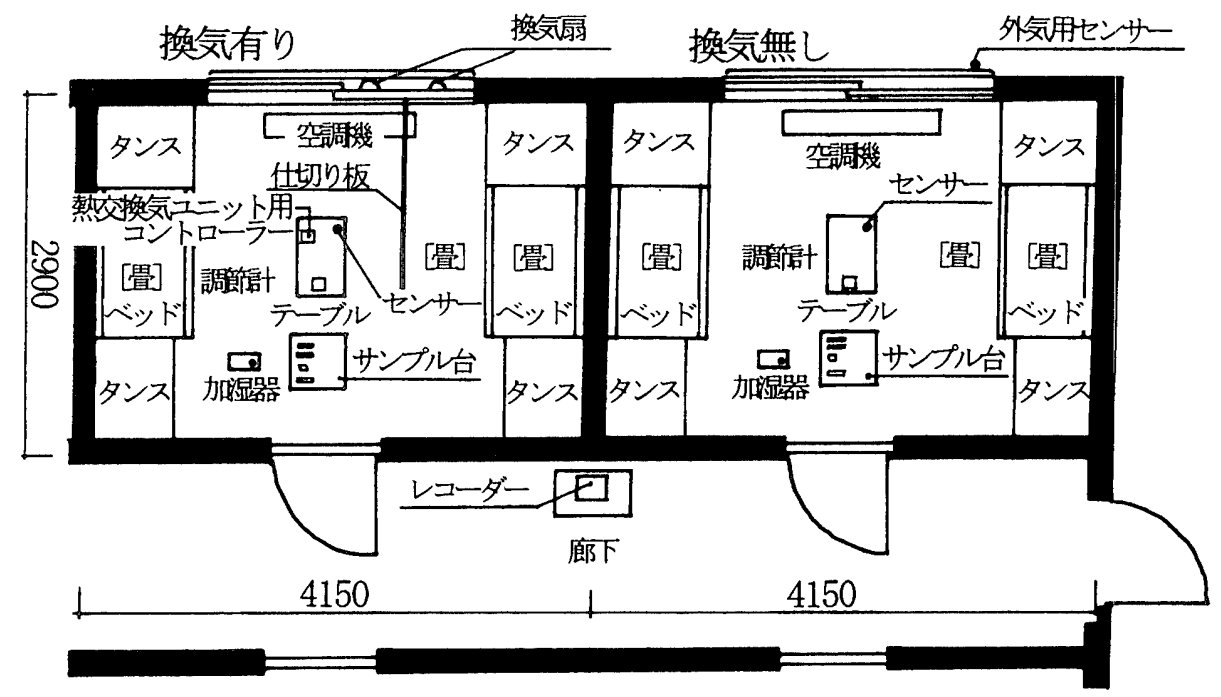

図 1 本実験で使用した居室の平面 


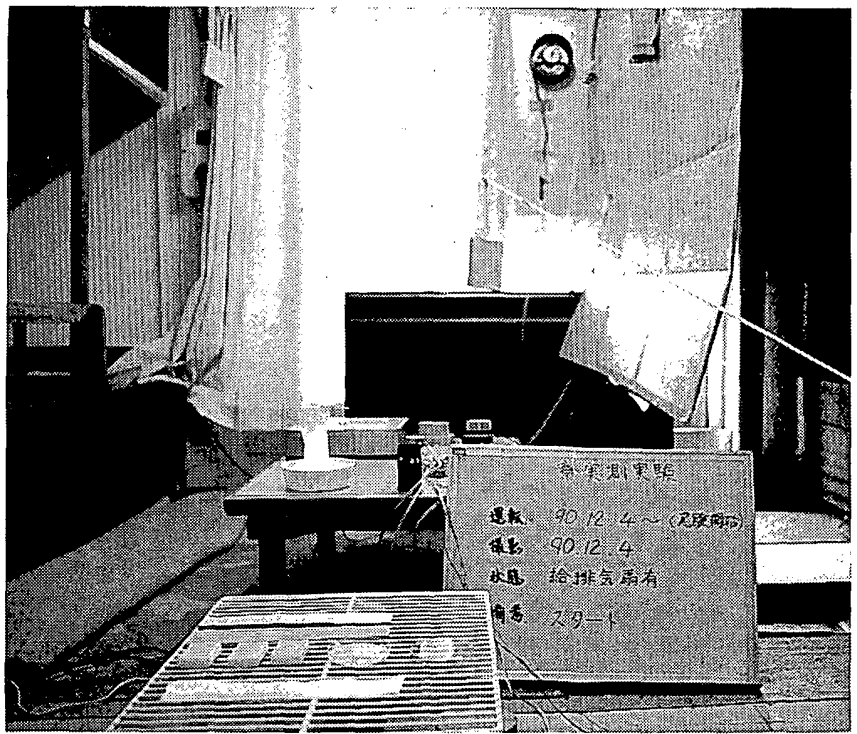

写具 1 基材並びに実験機器の設置状況
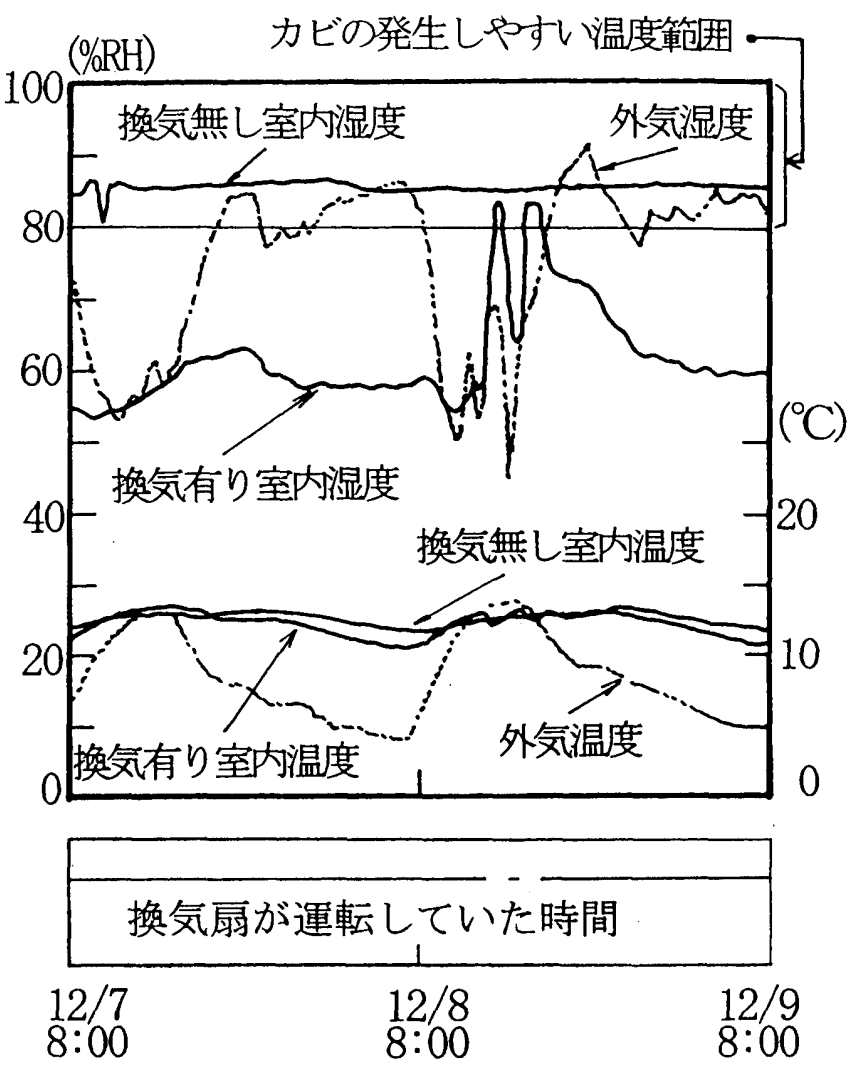

图 2 実験期間中のある 2 日間の室内外温湿度の経時変化

化を示寸。室温の変動範囲は、両部屋上も $12 \sim 14^{\circ} \mathrm{C}$ とによど差が 認められなかったが、室内相対湿度は、換気有りの部屋における値 が60〜83\%であり、換気無しの部屋の $85 \%$ に比心゙て、最大 $25 \%$ 程 度低かった。

また、2 日間の中でカビの発生しや寸い湿度80\%を越える頻度は、 換気無しの部屋で常時、換気有りの部屋で 1 時間づつ2回であった。
両室の熱負荷はほぼ同程度であり、日射の室内入射もほとんど無 い非暖房状態であったため、室温変動範囲が同程度であったと考え られる。換気を行った部屋の室内相対湿度は、換気無しの部屋にお ける值に比べ、常時低めであった。関東地方等の冬季における外気 中の絶対湿度は、常時、室内側に比べて低い状態であり、上述の工 ンタルピ比較制御運転を行うことが、低湿度の外気と室内の高湿度 の空気を入れ替えたことになったためであると考える。

図 3 に、前報1)で明らかにしたカビが生育しやすい温湿度範囲と、 換気有りの部屋ならびに換気無しの部屋の温湿度変動範囲との関倸 を示寸。

カビの生育しや寸い温湿度範囲と換気無しの部屋の温湿度変動範 囲を比較すると、カビが生えた餅の場合には、重複する領域があっ た。壁紙の場合、カビの生育しや寸い温湿度の範囲外であったにも 拘わらず、壁紙上へカビが生育した。前述のように、超音波加湿機 作動時に噴霧された霧状水滴により壁紙が濡れるようにしたため、 比較的高い湿度を維持した換気無しの部屋では壁紙からの水分蒸発 が殆どなく、壁紙が常時濡れた状態であった可能性がある。

換気有りの部屋の場合、測定期間中の室内湿度仕、換気により力 ビが生育しやすい温湿度範囲から适脱した值で換気無しの部屋にお ける湿度より低值を維持したので、壁紙が乾燥・湿潤を繰り返して いた可能性がある。

\section{3.実際の居室を用いた年間を通じての換気によるカビ污染防 止効果の険証ならびに换気厥自動制御方法の比較実験}

\section{1 実験目的}

前述の冬期に実施した実験は、室内相対湿度に比べ外気相対湿 度が低く、換気を行えば必ず室内相対湿度が低减する理想的な環境 下での実験であったと考えられる。

一般的に、カビ污染が発生する頻度が高い季節は、、温湿度とも が比較的高い梅雨や夏であると言われており、これらの季節におけ る外気の温湿度は冬期のそれと大きく異なっている。

そこで、施工途中のリゾートマンションの内装等の仕上げが終了 した 3 住戸を 1 年近くの長期間にわたって借用して、四季を通じて の換気のカビ污染防止に対寸る効果を検証した。また、換気扇の運 転方法の差異に伴う効果の相違を検討した。

\section{2 実験概要}

\section{（1）使用した基材}

前報1）で最も力ビが発生し易いと判明した畳在半畳分、各居室 に設置した。また、参考のため、日常品の内、最もカビが発生し易 い餅も設置した。

なお、前述の実験上異なり、基材に注人工的な污れを再現した 畉黄やカビ眯濁液を塗布しておらず、通常のまま上した。

(2) 使用した住戸

図4に、本実験で使用した居室の平面図在示寸。

新潟県湯沢町にある施工途中のリゾートマンションの 2 階東側に 位置する 3 住戸を使用した。3 住戸の床面䄼は各々 $30.09 \mathrm{ml}^{2}$ と等し く、気稹は72. $22 \mathrm{~m}^{3}$ である。これらの住戸怯、内装が仕上げられて おり、施工途中と言っても一般の住戸と変わらない。但し、コンク リート打設後の経過時間が短いので、コンクリートの固化に伴う蒸 
(C)

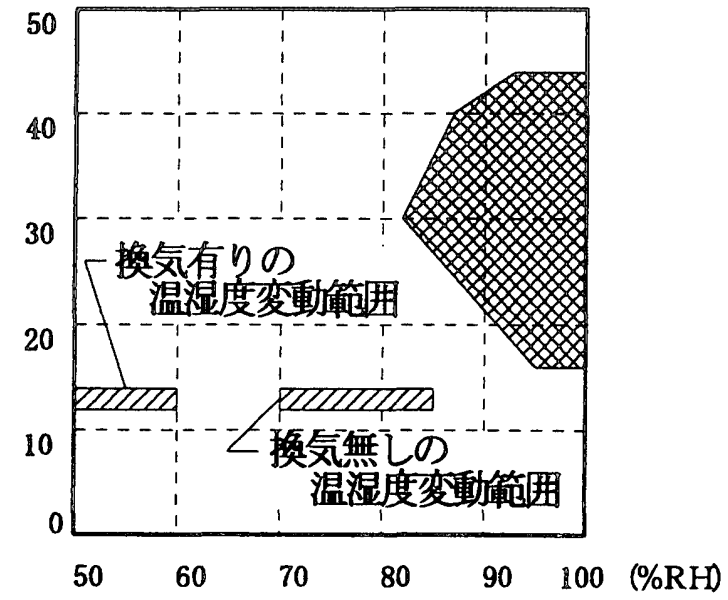

(C)

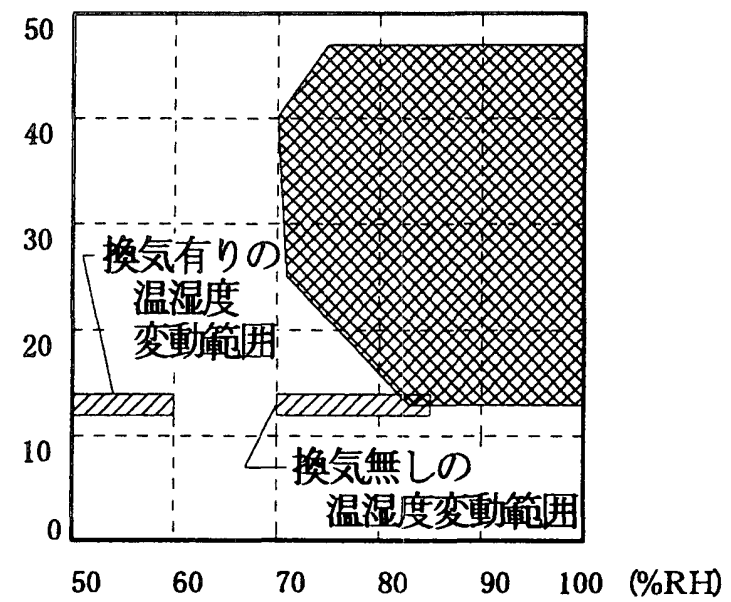

b ）餅

a）壁紙

\section{图 3 カビが発生しやすい温湿度䉇囲と室内温湿度变動䉇囲の関係}

発水分が室内に放出され続けていたと考えられる.

（3）実験方法

1) 実験期間・観察頻度

実験期間は、1992年7月から1993年6月までの11ヶ月であった。 便宜上、表 3 に示寸ように、実験期間を季節毎に分割した。

実験期間中、2 週間に 1 回、基材上八のカビの発生の有無、発生 後の生育面積を目視により観察した。

䒾 3 実験期間の季節分割

\begin{tabular}{|c|c|c|c|c|c|c|c|c|c|c|}
\hline $\begin{array}{r}92 . \\
7\end{array}$ & 8 & 9 & 10 & 11 & 12 & $\begin{array}{c}93 . \\
1\end{array}$ & 2 & 3 & 4 & 5 \\
\hline \multicolumn{2}{|c|}{ 世夏季 $\longrightarrow$} & \multicolumn{3}{|c|}{$\leftarrow$ 秋季 $\rightarrow$} & \multicolumn{3}{|c|}{ - 冬季 $\rightarrow$} & \multicolumn{3}{|c|}{$\leftarrow$ 春季 $\rightarrow$} \\
\hline
\end{tabular}

\section{2) 換気の調整方法}

実験対象とした 3 住戸の内、 2 戸は換気有りとし、各住戸の台所 に設置してある換気扇を自動制御運転した。

エンタルピを検出するセンサーが高価でするここを考慮して、よ り赛用性の高い自動制御方法の検討を試みた。表4に示寸ように、 外気エンタルピが室内空気エンタルピより低い時だけ換気を行うエ ンタルピ比較制御の他、室温と外気温を比較して外気温が室温より 低い場合のみ換気扇を運転寸る温度比較制御も実験対象上した。

換気無しの住戸は、空・給気口とま閉鎖したままこした。

表 4 換気瀜自動制御方法

\begin{tabular}{|c|c|c|}
\hline & 換気扇運転 & 換気扇停止 \\
\hline $\begin{array}{c}\text { 温度比較制御 } \\
\text { (内外の温度 } \\
\text { を比較) }\end{array}$ & $\begin{array}{c}\text { 室内温度 } \\
\quad>\text { 外気温度 }\end{array}$ & $\begin{array}{l}\text { 室内温度 } \\
\quad<\text { 外気温度 }\end{array}$ \\
\hline 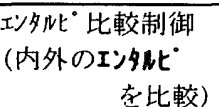 & 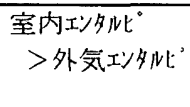 & 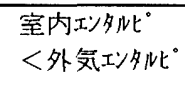 \\
\hline
\end{tabular}

3 住戸の換気状況を定量的に把握するため、「JIS A 1406 屋 内換気量測定法（炭酸ガス法）」2）に従って、換気回数を測定した。
測定結果を表 5 に示すが、換気無しの住戸の換気回数や換気扇停止 時の換気回数は 0.5 回程度と漏気による換気が行われていたが、換 気扇運転時の換気回数は $2 \sim 3$ 倍に達しており、換気の有無による 換気量の差異は有意であると言えよう。

表 5 換気回数澗定結果

\begin{tabular}{|c|c|c|}
\hline & 換気有りの住戸 & 換気無しの住戸 \\
\hline 換気扇ON & $0.8 \sim 1.9$ 回 $/ \mathrm{h}$ & - \\
\hline 換気扇OF F & $0.4 \sim 0.6$ 回／h & $0.4 \sim 0.6$ 回，h $\mathrm{h}$ \\
\hline
\end{tabular}

\section{3) 実験条件}

実験状況を写真 2 に示寸。

各住戸とも、空面にカーテンを設けて、直達日射が室内に侵入し ないようにした。

夏季・秋季は、自然室温の状態としたが、冬季や春季は屋外条件 を考慮し、400Wの電気ヒーターで加熱すると共に、水を溜めた水槽 を室内に設置して加湿した。

各部屋の室内温湿度経時変化は、神栄株式会社製温湿度センサー （RHU-650-232）を用いて自動測定した。サンプリング間隔は、10 分とした。

4 ) 評価尺度

前述のJIS Z 2911に準じた 4 段階評価尺度を用いた。

\section{3 実験結果、及び、考察}

表 6 に、温度比較で換気を行った住戸 (以下温度比較換気住戸) とエンタルピ比較で換気を行った住戸（以下エンタルピ比較換気住 戸)、換気無し住戸にお打る基材上へのカビ発生状況に関寸る観察 結果を示す。

餅は各季節毎に新しいものを設置し值した。睤(1)本実験当初 から設置していたものであり、畳(2) である。 


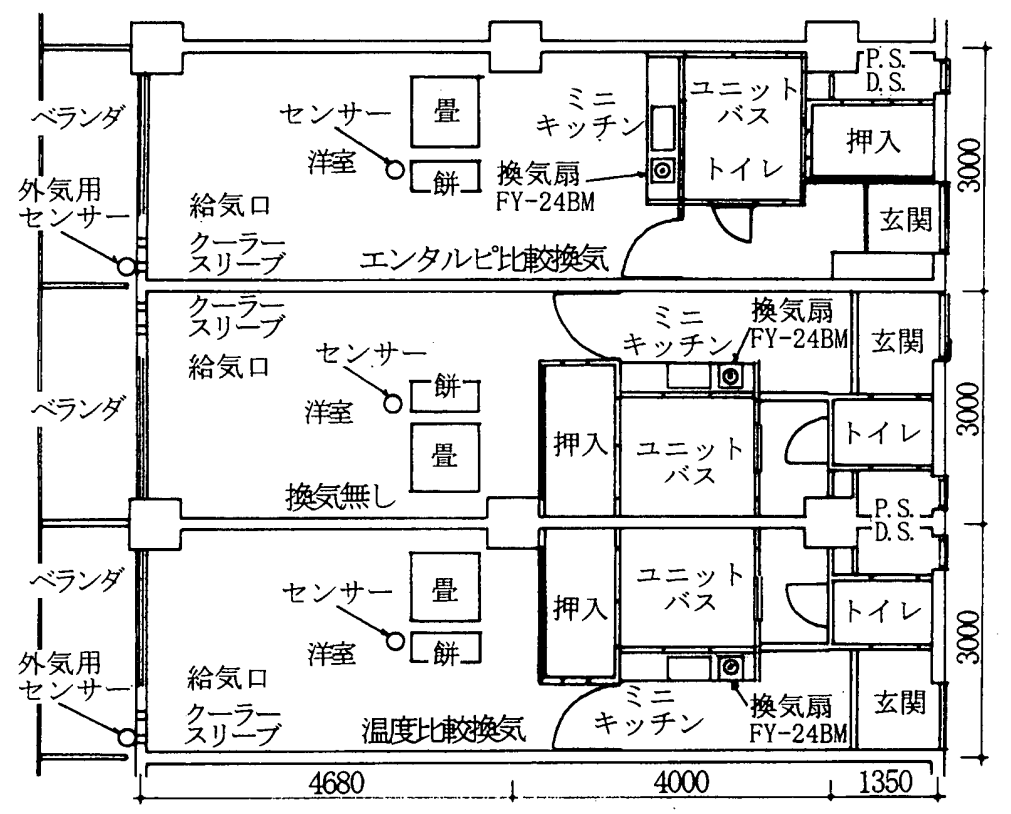

図 4 本実験で使用した居室の平面

表 6 換気の有恕、制御手段の違いによる カビ発生状況の差異

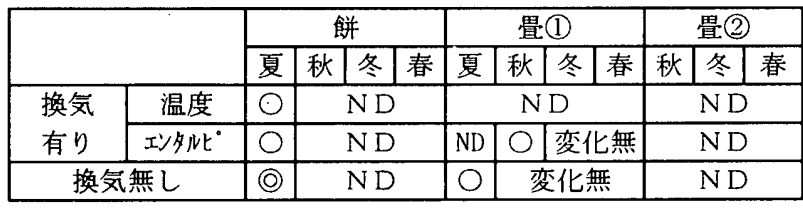

菌系の生育が認められない

菌系の生育面積が全面積の $1 / 3$ 未満・・・O

菌系の生育面積が全面積の $1 / 3$ 以上・・・ (仓)

餅の場合、夏季において、全ての住戸ともにカビが発生したが、 換気の有無により生育面積に差異が認められた。元の他の季節にお いては、換気の有無に拘わらずカビの生育は認められなかった。温 度比較換気住戸のみ、四季在通じて、嘼(1)に柱カビが発生しなかっ た。換気無し住戸恃夏季に、エンタルピ比較換気住戸汢秋季に、睤 (1)にカビが発生し、以降、カビの発育に変化は認められなかった。 畳(2)に関しては、全住戸とも、カビの発生は認められなかった。基 材に発生したカビ菌種の内、同定作業で確認できたものは Aspergillus属注ii)注iii)であった。ただし、本実験は実際の居 室を用いたフィールド実験であるため、暴露基材である毘の上に一 種類の菌種のみが生育寸るとは考え難く、実際に㳉他の優先種が育 成していた可能性がある。

図 5 に、夏季のある 2 日間における室内外の温湿度の経時変化 を示寸。

換気有り 2 住戸の室温と換気無し住戸の艺れとは、 $28^{\circ} \mathrm{C}$ とほとん ど差は認められなかった。室内相対湿度に関して㳉、温度比較換気 住戸が68～75\% と最も低く、エンタルピ比較換気住戸が $72 \sim 76 \%$ 、 換気無し住戸が最も高く80〜 $82 \%$ であった。また、秋季においても 夏季と同様の傾向が見られ、3住戸とも室温は20ㄷと汪とんど差が 認められ寸゙、室内相対湿度俚温度比較換気住戸が $58 \sim 68 \%$ と最も低く、
エンタルピ比較換気住戸が63〜 70\%、換気無し住戸が最も高く66〜72\% であった。

換気を行っていたにも倸らず、温度比較換気住戸、並びに、エン タルピ比較換気住戸の室内相対湿度に变動が見られなかったのは、 室内空気環境が非居住状態であったため、水蒸気発生量が居住状態

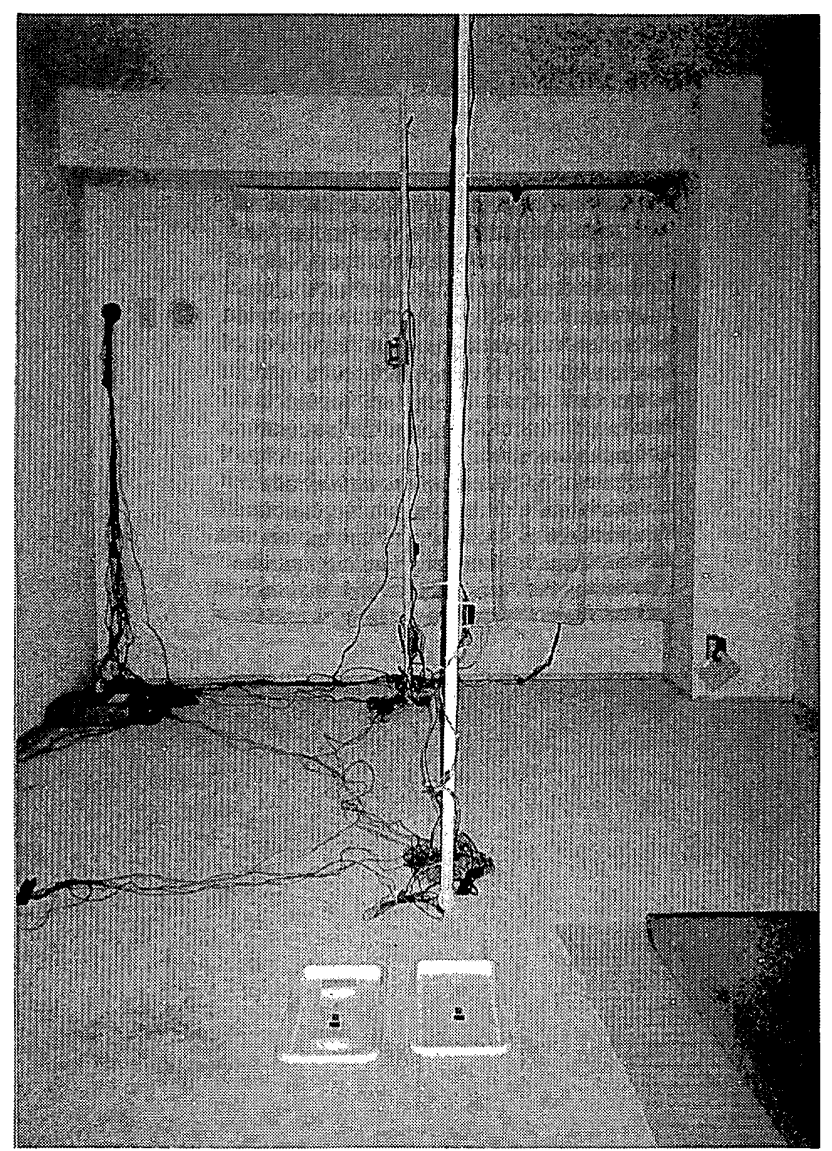

写真 2 実験機器設置状況 
に比バ微量であったこ上が考えられる。しかしながら、換気有り 2 住戸の相対湿度は、換気無し住戸の关れよりも低い值学維持してい たこレから、換気により室内の相对湿度を低くできたっ考えられよ 5 .

図6に、前報1)で明らかになったカビが生育しや寸い温湿度範囲 上換気有り 2 住戸（温度比較換気住戸上エンタルピ比較換気住戸）、 並びに、換気無し住戸における温湿度の出現範囲との関係を季節別 に示寸

夏季の場合、3 住戸上も、餅上にカビが発生しや小い温湿度範 曲上室内に抢ける温湿度の出現範囲が大幅に重複した。このため、 前掲の表 6 に示古上うに、全住戸上き餅俋力ビが発生したよ推定で きよう。睤に関しては、温度比較換気住戸にお汁万温湿度の出現範 井のみ、畳に力ビが発生しや寸い温湿度範囲から外れていた：エン

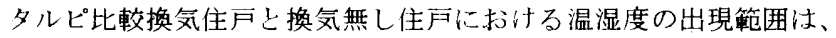
畳にカビが発生しや寸い温湿度範囲と重複していたが、エンタルピ 比較換気住戸の場合、艺の出兒頻度什744時間中28時間であったの に対し、換気無しの出現頻度い744時間中78時間上約3倍であった このような出現頻度の多少が原因て、エンタルピ比較換気住戸の場 合、胃(1)に力ビが発生せざ、換気無し住戸の次畺(1)にカビが発生し たと考えられる

秋季における 3 住戸の室内温湿度の出現範囲柱、畳にカビが発 生しや寸い温湿度籍囲から外れていた。しかしながら、エンタルピ 比較換気住戸のみ、畳(1)にカビ発生が認められた。この理由は不明 である。ただし、今回測定した住戸があるマンションは施工途中で あったため、工事の関倸で停電事故が数日間発生していた。この測 定データーが欠落した期間中、エンタルピ比較換気住戸における室 内温湿度の出現範囲がカビの育成しや寸い温湿度篹囲と重複してい た可能性もある。さらに、前報でも述べたように、カビが発生しや すい温湿度籍囲を特定寸るための実験では、人工的な污れを再現寸 るために卵黄を塗布したので、成長に時間が掛かる環境下でのカビ の発生を捉えられなかった可能性が高かった。測定結果に基づけげ、 8月下旬のエンタルピ比較換気住戸における室内温湿度の出現範囲 上畳にカビが発生しや寸い温湿度範囲とが、一部重複しており、こ の点を勘案すると、夏季から秋季に及ぶ長時間を掛けてカビが発生 した可能性も考えられる。

冬季および春季における室内温湿度の出現範囲は、3 住戸とも、 畳にカビが生育しやすい温湿度が大きく外れていた。400Wの電気 ヒーターと自然蒸発による加湿程度では、室内発生水蒸気量が実際 の居住状態に比べて微量であったため、基材上へカビが発生しな かったと考える。

以上のことから、外気中の水蒸気分圧が高くなる夏季、秋季にお ける室内カビ污染防止に対寸る換気の効果を明らかにした。また、 換気扇の自動制御運転方法に関しては、温度比較換気の方がエンタ ルピ比較換気に比べ、効果があるという結果が得られた。但し、温 度比較換気の場合、梅雨時など水蒸気分圧の高い外気を導入放 れがあるので、さらに検討を行う必要が有らう。
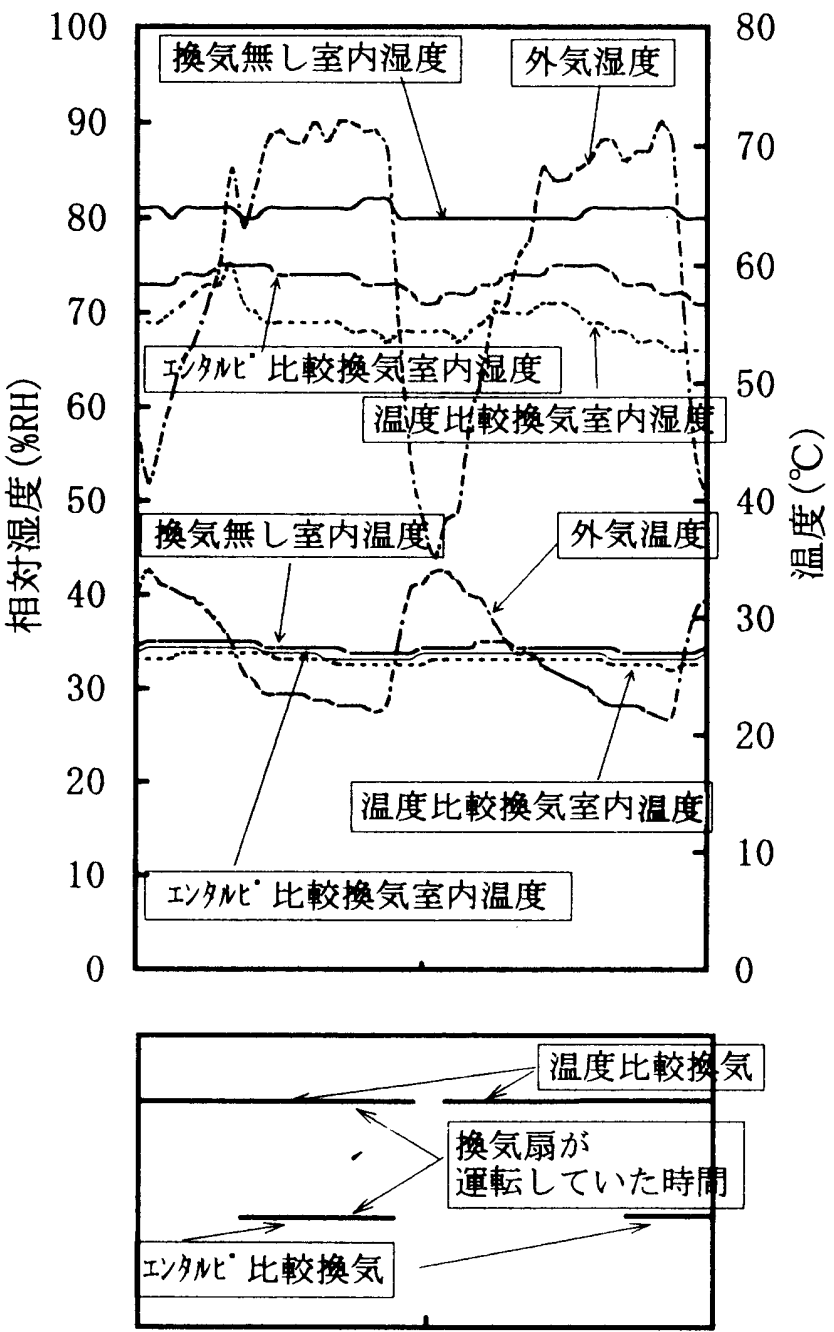

8/29 8:00

8/30 8:00

8/31 8:00

因 5 夏季のある 2 日間における 室内外温湿度の経時変化 


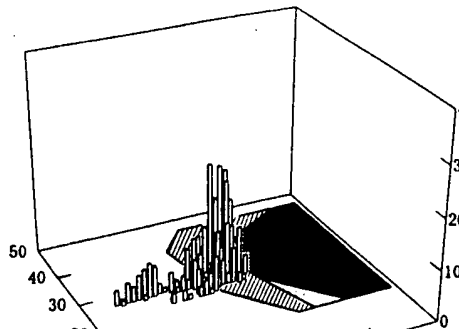

温度 $\left({ }^{\circ} \mathrm{C}\right)^{2}$
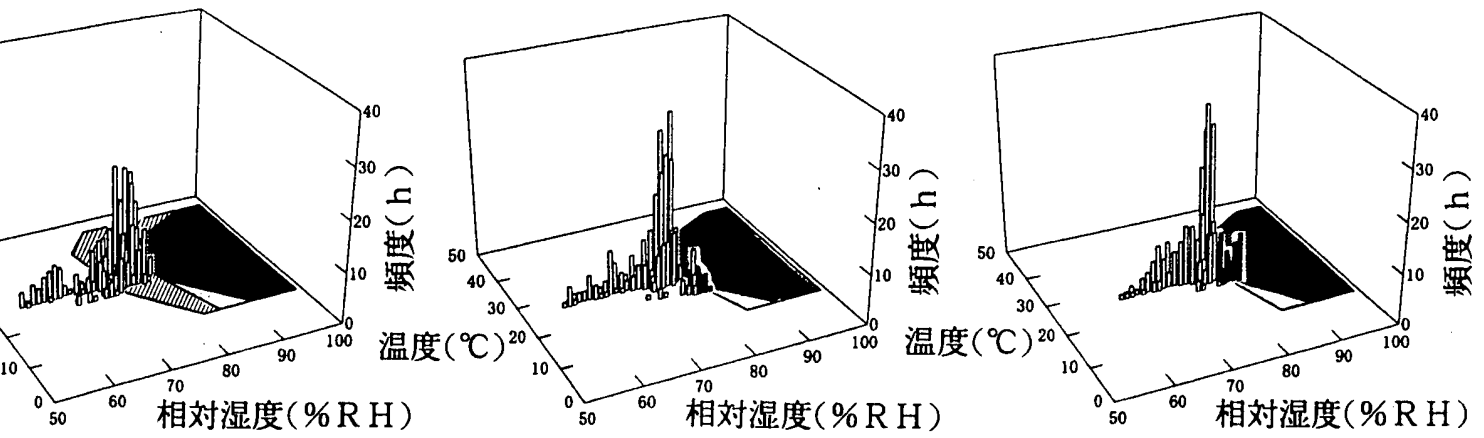

a) 夏手

温度比較換気

エンタルピ比較換気

換気無
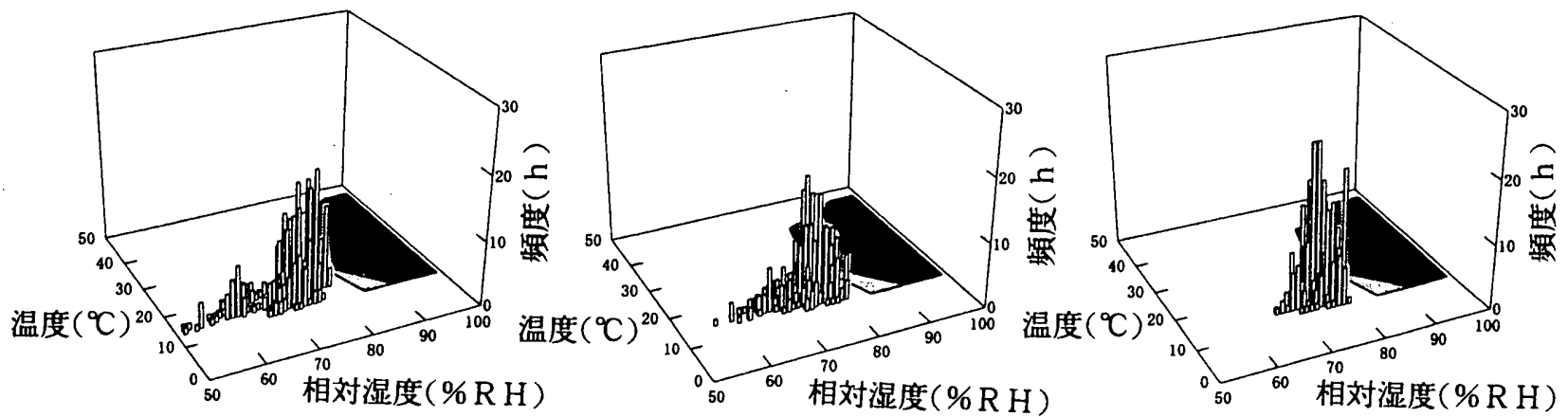

b) 秋

温度比較換気

エンタルピ比較換気

換気無
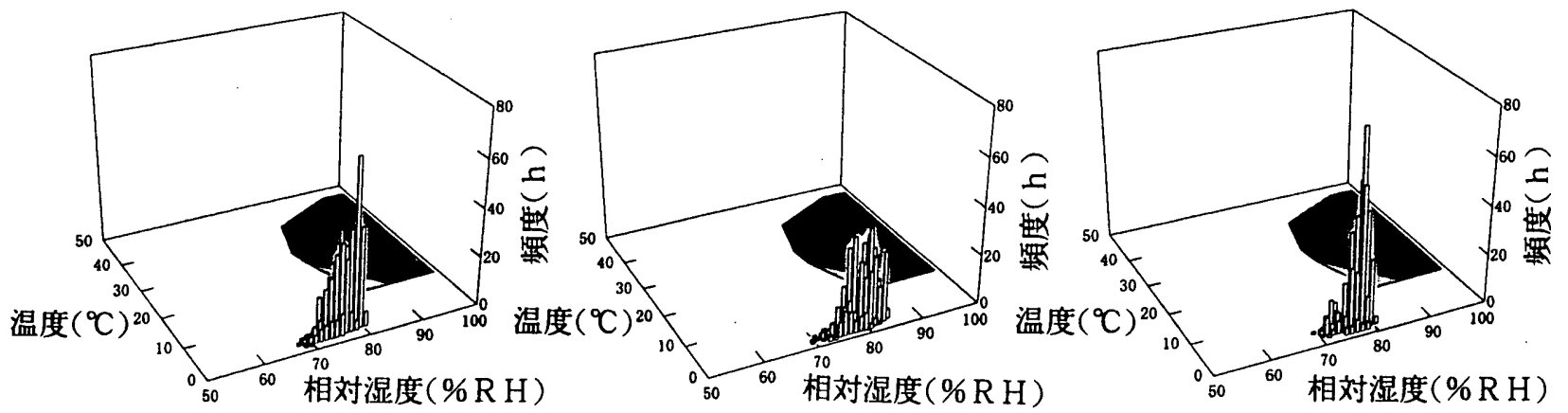

c) 冬亲

温度比較換気

エンタルピ比較換気

換気無
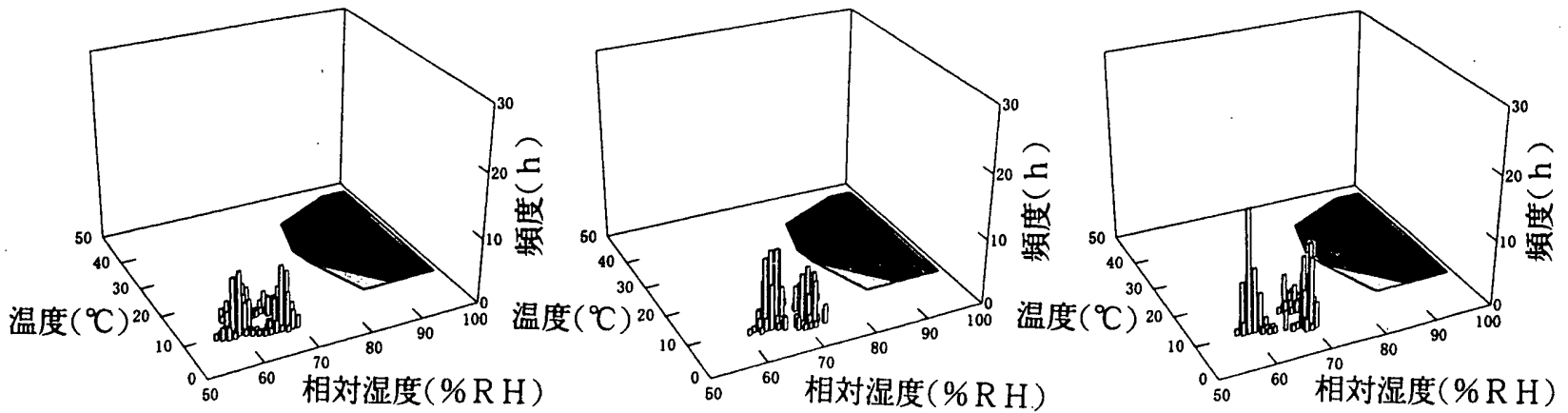

d) 替乎

菌種：Aspergillus属 基材：畳表・餅

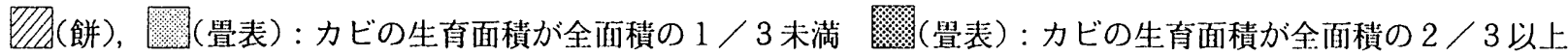
$\square$ : カビの生育する危険性が低い室内温湿度 : カビの生育する危険性が高い室内温湿度

图 6 カビの生育しやすい温湿度䉇囲と各部屋の季節每の空内温湿度変動範囲との関係 
4. 結語

従来、経験則的に言われてきた換気の室内カビ污染防止に関する 実物実証実験を行い、以下のことを確認した。

(1) 換気の有無により、室内におけるカビ発生状況 に差異が認められた。

（2）換気を行った場合、室内水蒸気分圧が低減し、 室内相対湿度が建材上にカビが発生し易い温湿度 篡囲から逸脱した值を維持した。

(3) 換気が室内温就環境に与える影響を考慮すると、 換気はカビ污染防止に対する効果があると言えよう。

(4)この効果は、関東地方等の場合、外気中の水蒸 気分圧が低い冬季だけでなく、四季を通じて有る ことを検証した。

(5) 換気扇の自動運転制御方法に関しては、温度比 較換気の方がエンタルピ比較換気より若干ではあ るが効果的であった。センサーの価格等、実用性 を考虑すると、温度比較換気を採用することも考 えられよう。

但し、本研究は関東地方等の一地域における非居住状態の居室を 用いた模擬的な実験であり、他の地方や実際の居住状態の多種の発 生源からの多量の発湿が再現されていない。今後、詳細な検討を行 うためには、実際の居住状態での実大実験を行う必要が有ると考え る。また、温度比較換気に関しても、梅雨時な上゙外気の水蒸気分圧 が高い場合に対寸る配慮を検討寸る必要がある。

\section{韵辞}

本研究を実施寸るに際して、住友建設 (株) 建築本部設備環境部、 同東京支店のご協力をいただきました。ここに記して、感謝の意 を表します。

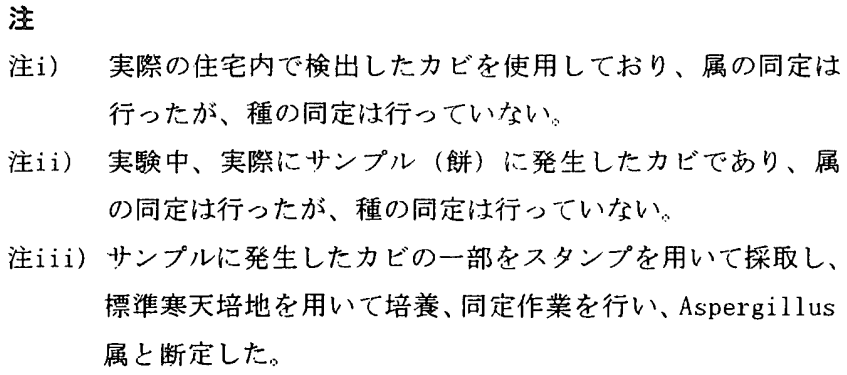

\section{参考文献}

1）小峯裕己、小座野貴弘、長谷川永、末永義明： 住宅室内のカビ污染上防止に関寸る研究、日本建築学会 計画系論文報告集、No. 484、1996年6月

2）日本規格協会：JIS A 1406-1974, “屋内換気量測定方法(炭酸ガス法)" pp. 470, （財）日本規格協会, 1995

3）日本規格協会：JIS Z 2911-1981，JI S ハンドブック, 24巻, pp. 430，（財）日本規格協会， 1987

4 ）山里一英、横山和正他 : 微生物の分離法 R\&:IJソシシンング 1986

（1996年 7 月 9 日原稿受理， 1996年12月18日採用決定） 